\title{
Correction to: An Investigation into Sinterability Improvements of 316L Binder Jet Printed Parts
}

\author{
RASIM BATMAZ, ALI ZARDOSHTIAN, TREVOR D. SABISTON, \\ REZA TANGESTANI, APRATIM CHAKRABORTY, NICHOLAS KRUTZ, \\ SRINIVAS PENDURTI, ARUNKUMAR NATARAJAN, and ETIENNE MARTIN
}

https://doi.org/10.1007/s11661-022-06596-3

(c) The Minerals, Metals \& Materials Society and ASM International 2022

\section{Correction to: \\ Metallurgical and Materials Transactions A (2021) \\ https://doi.org/10.1007/s11661-021-06564-3}

Arunkumar Natarajan's family name is correct as reflected here. The original article was corrected.

Publisher's Note Springer Nature remains neutral with regard to jurisdictional claims in published maps and institutional affiliations.

ETIENNE MARTIN is with Polytechnique Montréal, 2500 Chemin de Polytechnique, Montréal, QC H3T 1J4, Canada. Contact email: etienne.martin@polymtl.ca. RASIM BATMAZ, ALI ZARDOSHTIAN, TREVOR D. SABISTON, REZA TANGESTANI and APRATIM CHAKRABORTY are with the University of Waterloo, 200 University Ave W, Waterloo, ON N2L 3G1, Canada. SRINIVAS PENDURTI, ARUNKUMAR NATARAJAN and NICHOLAS KRUTZ are with the GE Additive, 8556 Trade Center Dr, West Chester, OH, 45011, USA.

The original article can be found online at https://doi.org/10.1007/ s11661-021-06564-3.

Article published online March 1, 2022 